\title{
Hepatoprotective activity of whole Plant Extract of Catharanthus Pusillus (Murr.) G.Don (Apocynaceae)
}

\author{
Yokeswari Nithya, P Ananthi, S Mohan, V.R
}

\begin{abstract}
CCl}_{4}$ intoxicated rats showed significant elevation in serum enzymes, bilirubin and lipid per oxidation of the liver tissues and reduction in serum total protein, superoxide dismutase, catalase, reduced glutathione and glutathione peroxidase activity. Treatment with ethanol extract of Catharanthus pusillus whole plant altered the above parameters to the levels of near normal. All the above results were comparable with the standard drug silymarin $(100 \mathrm{mg} / \mathrm{kg})$ treated group. Thus the present study ascertains that the ethanol extract of Catharanthus pusillus whole plant possesses significant hepatoprotective activity.
\end{abstract}

Keywords: Catharanthus pusillus, CCl4, silymarin, bilirubin

\section{INTRODUCTION}

Liver disease has become a global concern worldwide. Liver is often abused by environmental toxins, poor eating habits and alcohol, that damage and weaken the liver leading to important public health problems like hepatitis, cirrhosis and alcoholic liver diseases (Treadway, 1998). India, numerous medicinal plants and their formulations are used for treating liver disorders in traditional systems of medicine. Herbal drugs play an important role in treatment of various ailments including liver problems . Therefore, many folk remedies from plant sources are being tested for their potential hepatoprotective activity in experimental animal models (Ganga Rao et al., 2012).

Catharanthus pusillus of Apocynaceae family is known with various names in India and all over the world. It is widely used as various treatments of diseases and traditionally used as herbal medicine (Don ,1999). The roots, leaves and latex of these plants are used to treat skin and liver diseases, leprosy, dysentery, worms, ulcers, tumor and ear aches. The leaf powder of C.pusillus were mixed with coconut oil and used for treat the antidandruff activity and also used to kill the lice (Rajakaruna,2002). The main purpose of this study was to know about the hepatoprotective

Revised Manuscript Received on November 22, 2019.

Yokeswari Nithya, Department of Chemistry, A.P.C.Mahalaxmi College for Women,Thoothukudi, Tamil Nadu

P Ananthi, Department of Chemistry, Vidhya Sagar Women's College,Chengalpattu, Tamil Nadu, India.

S Mohan, V.R, Professor, Department of Biomedical Science and Technology, Noorul Islam Centre for Higher Education, Kumaracoil, Thukalay - 629 180, Tamil Nadu, India activity of whole plant extract of C.pusillus on $\mathrm{CCl}_{4}$ induced liver toxicity in rats.

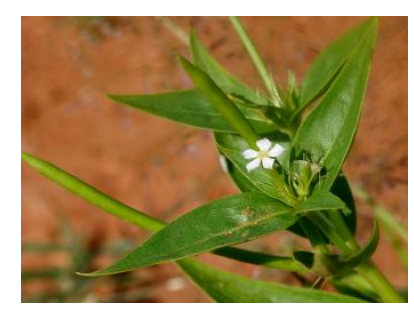

\section{MATERIALS AND METHODS}

Plant Material:

The whole plant of Catharanthus Pusillus were agglomerated from Pechiparai, Kanayakumari District, Tamil Nadu. With the help of local flora, voucher specimens were identified and preserved in the Ethnopharmacology unit, Research department of Botany, V.O.Chidambaram College, Thoothukudi, Tamil Nadu for further references

\section{Preparation of plant extract:}

The whole plant was shade dried and then powdered to obtain a coarse powder, which was then subjected to extraction in a Soxhlet apparatus using ethanol. The extract was tested for the identification of various phytochemical constituents as per standard procedures (Brinda,1981\&Lala, 1993.,).The ethanol extracts were concentrated in a rotary evaporator. The concentrated ethanol extract were used for study.

\section{Experimental animal}

Adult male wistar albino rats weighing about 180 $240 \mathrm{~g}$ body weight were selected for this work. They were abide under standard environmental conditions at room temperature $\left(25 \pm 2^{\circ} \mathrm{C}\right)$ in a well-ventilated animal house with constant $12 \mathrm{~h}$ of darkness and $12 \mathrm{~h}$ of light schedule. The rats were fed with standard pellet diet (Goldmohar brand, Hindustan Lever Ltd., Mumbai, India) and water ad libitum.

\section{Acute Toxicity Studies}

Acute oral toxicity study was performed as per OECD-423 guidelines (acute toxic class 
method), albino rats $(\mathrm{n}=6)$ of either sex selected by random sampling were used for acute toxicity study (OECD 2002.,)

\section{EXPERIMENTAL PROTOCOL}

\section{Induction of hepatotoxicity}

Carbon tetrachloride $\left(\mathrm{CCl}_{4}\right) 2.5 \mathrm{ml} / \mathrm{kg}$ body weight was dissolved in $7.5 \mathrm{ml}$ of paraffin and administered intraperitoneally.

\section{Grouping of animals}

A total of 30 rats were taken and were divided into six groups of 5 rats each, of which, five groups contained $\mathrm{CCl}_{4}$ hepatic toxicity induced rats and the remaining one group contained normal rats.

Group - I : Rats received normal saline $(0.9 \%)$, by
using an intragastric catheter tube
(IGC)- Normal control

Group - II : Liver injured rats received $2.5 \mathrm{ml} / \mathrm{kg}$ body weight of normal saline $(0.9 \%)$ for 14 days, by using IGC, $-\mathrm{CCl}_{4}$ hepatic toxicity induced control.

Group-III : Liver injured rats received C.pusillus whole plant ethanol extract at the dose of $150 \mathrm{mg} / \mathrm{kg}$ body weight for 14 days, by using an IGC.

Group-IV : Liver injured rats received C.pusillus whole plant e than ol extract at the dose of $300 \mathrm{mg} / \mathrm{kg}$ body weight for 14 days, by using an IGC.

Group - V : Liver injured rats received C.pusillus whole plant e than ol extract at the dose of $500 \mathrm{mg} / \mathrm{kg}$ body weight for 14 days, by using an IGC.

Group-VI : Liver injured rats received silymarin orally at the dose of $100 \mathrm{mg} / \mathrm{kg}$ body weight for 14 days, by using an IGC.

All the treatments were given between 9.30 and 10.00 in the morning. After $24 \mathrm{~h}$ of last treatment, the final body weight was noted and the animals were sacrificed by decapitation. Blood was collected from each group of rats. Serum from the blood was separated by centrifugation at $3000 \mathrm{xg}$ for $10 \mathrm{~min}$ and stored at $-20^{\circ} \mathrm{C}$ until used for various biochemical assays. Estimation of GGT, Protein, Serum Glutamate Oxalo Transaminase (SGOT or AST), Serum Glutamate Pyruvate Transaminase (SGPT or ALT) and Alkaline Phosphate (ALP) was done as per the standard procedures.

\section{Estimation of Total, Conjugated and Unconjugated Bilirubin}

Total bilirubin and conjugated bilirubin were determined as described by Balistrei and Shaw (1987). The concentration of unconjugated bilirubin was the difference between total and conjugated bilirubin concentrations.

\section{Estimation of Serum MDA, SOD, CAT, GPx and GRD}

Quantitative estimation of MDA formation was done by the method proposed by Okhawa et al. (1979) and it was done by determining the concentration of thio barbituric acid reactive substance (TBARS) in serum. Enzymatic antioxidants, superoxide dismutase (SOD) (Mishra, 1972), Catalase (Aebi, 1974), non enzymatic antioxidant glutathione peroxidase (GPx) (Paglia and Valentine, 1967), glutathione reductase (GRD) (Goldberg and Spooner, 1983) and reduced glutathione (GSH) were also assayed in serum.

\section{Biochemical Analysis}

The animals were betrayed at the end of experimental period of 14 days by decapitation. Blood was collected, sera separated by centrifugation at $3000 \mathrm{~g}$ for 10 minutes. Serum protein and serum albumins was determined quantitatively by colorimetric method using bromocresol green.( Lowry et al., 1951). The total protein minus the albumin gives the globulin. Serum glutamate pyruvate transaminase (SGPT), serum glutamate oxaloacetate transaminase (SGOT), serum alkaline phosphatase (ALP), total, conjugated bilirubin, unconjugated bilirubin were determined as per the standard procedures (Shanmugasundaram et al.,2010 \& Thangakrishnakumari et al., 2012) . Liver homogenates $(10 \% \mathrm{~W} / \mathrm{V})$ were prepared in ice cold 10mM tris buffer ( $\mathrm{pH} 7.4)$. Quantitative estimation of MDA formation was done by determining the concentration of thiobarbituric acid reactive substances (TBARS) in 10\% liver homogenates by the method of Pal et al (Pal et al.,2011). Antioxidants such as superoxide dismutase (SOD), catalase (CAT), glutathione peroxidase (GPx) and glutathione reductase (GRD) were also assayed in liver homogenates as per the standard procedures (Anitha et al., 2010 \& Suky et al., 2011)

\section{Statistical Analysis}

The data were expressed as the mean \pm S.E.M. The difference among the means has been analyzed by one-way ANOVA. $p<0.05$ and $p<0.01$ were considered as statistical significance using SPSS Software. 


\section{RESULTS}

\section{Body weight}

The administration of $\mathrm{CCl}_{4}$ caused a significant $(p<0.01)$ decrease in the body weight of rats as compared with the control rats. The animals treated with whole plant extract of C.pusillus (150 mg/kg, $300 \mathrm{mg} / \mathrm{kg}$ and $500 \mathrm{mg} / \mathrm{kg}$ ) also gained weight during the experimental period (Table 1).

Table 1: Effect of whole plant ethanol extract of C.pusillus on the body weight in the normal, liver damaged and drug treated rats.

\begin{tabular}{|l|l|l|l|l|l|}
\hline Treatment & Dose & $\begin{array}{l}\text { Initial Body weight } \\
(\mathrm{Gm})\end{array}$ & $\begin{array}{l}\text { Final Body weight } \\
(\mathrm{Gm})\end{array}$ & $\begin{array}{l}\text { Mean weight } \\
\text { Gain }(\mathrm{G} \uparrow) / \text { loss } \\
(\downarrow \downarrow)(\mathrm{Gm})\end{array}$ & \% of \\
Difference \\
\hline Group I & $0.9 \%$ Saline & $219.65=6.24$ & $226.16=3.86$ & 6.51 & 2.96 \\
\hline Group II & $0.9 \%$ Saline & $226.60=5.65$ & $211.65=2.84 * *$ & $15.15^{* 8}$ & 6.67 \\
\hline Group III & $150(\mathrm{mg} \mathrm{Kg})$ & $215.60=4.16$ & $206.16=3.64 * *$ & 9.44 & 4.37 \\
\hline Group IV & $300(\mathrm{mg} \mathrm{Kg})$ & $224.50=3.84$ & $216.18=4.16^{*}$ & $8.32 \mathrm{a}$ & 3.70 \\
\hline Group V & $500(\mathrm{mg} \mathrm{Kg})$ & $218.13 \pm 5.18$ & $214.84=3.92 \mathrm{~ns}$ & $3.29 \mathrm{aa}$ & 1.50 \\
\hline Groups VI & $100(\mathrm{mg} \mathrm{Kg})$ & $221.65 \pm 4.96$ & $218.16=4.86 \mathrm{~ns}$ & $3.49 \mathrm{aa}$ & 1.57 \\
\hline
\end{tabular}

Values are mean \pm SD of 5 animals in each group. Statistical analysis ANOVA followed by Dunnett t-test. $* P<0.05$; **P $<0.01$ as compared with Normal Control to liver damaged control: a $P<0.05$; aa $P<0.01$; aaa $P<0.001$ as compared with liver damaged control to drug treated animal ns: not significant.

\section{Biochemical parameters}

The results of serum biochemical parameters are presented in Table 2. In the $\mathrm{CCl}_{4}$ control group, significant $(p<0.05 ; p<0.01)$ decrease in the levels of total protein, albumin and globulin was observed. But the group which received the drug of whole plant extract at the dose of 500 $\mathrm{mg} / \mathrm{kg}$ body weight showed a significant $(p<0.01)$ increase in the reduced levels of protein albumin and globulin. The elevation of SGOT, SGPT and ALP in $\mathrm{CCl}_{4}$ intoxicated rat was significantly $(p<0.01)$ high when compared to the normal. The elevated levels of SGOT, SGPT and ALP in groups IV and V rats (post treated with whole plant extract, $300 \mathrm{mg} / \mathrm{kg}$ and $500 \mathrm{mg} / \mathrm{kg}$ ) were significantly $(p<0.05$; $p<0.01$ ) low as depicted in Table 2.

Table 2: Effect of whole plant ethanol extract of C.pusillus on the serum protein, albumin, globulin concentration and serum GOT, GPT and ALP enzyme activity in the normal, liver damaged and drug treated rats.

\begin{tabular}{|c|c|c|c|c|c|c|c|c|}
\hline \multirow[b]{2}{*}{ Groups } & \multicolumn{8}{|c|}{ Parameters } \\
\hline & Dose & $\begin{array}{l}\text { T. Protein } \\
\text { (g/dl) }\end{array}$ & $\begin{array}{l}\text { Albumin } \\
(\mathrm{g} / \mathrm{dl})\end{array}$ & $\begin{array}{l}\text { Globulin } \\
(\mathrm{g} / \mathrm{dl})\end{array}$ & $\begin{array}{l}\text { A/G } \\
\text { Ratio }\end{array}$ & SGOT (U/L) & SGPT (U/L) & ALP (U/L) \\
\hline Group I & $\begin{array}{l}0.9 \% \\
\text { saline }\end{array}$ & $9.36 \pm 0.36$ & $5.11 \pm 0.26$ & $4.25 \pm 0.54$ & $1.20: 1$ & $22.96 \pm 1.34$ & $27.16 \pm 1.56$ & $162.65 \pm 5.67$ \\
\hline $\begin{array}{l}\text { Group } \\
\text { II }\end{array}$ & $\begin{array}{l}0.9 \% \\
\text { saline }\end{array}$ & $\begin{array}{l}7.56 \pm 0.54^{*} \\
\approx\end{array}$ & $4.16 \pm 0.36^{*}$ & $3.40 \pm 0.21^{*}$ & $1.20: 1$ & $\begin{array}{l}86.92 \pm 1.69 * \\
*\end{array}$ & $\begin{array}{l}73.64 \pm 2.16^{*} \\
*\end{array}$ & $\begin{array}{l}248.65 \pm 9.27 * \\
*\end{array}$ \\
\hline $\begin{array}{l}\text { Group } \\
\text { III }\end{array}$ & $\begin{array}{l}150 \\
\mathrm{mg} / \mathrm{kg}\end{array}$ & $7.86 \pm 0.37 *$ & $\begin{array}{l}4.54 \pm 0.16 n \\
s\end{array}$ & $3.32 \pm 0.16^{*}$ & 1.40:1 & $\begin{array}{l}73.16 \pm 1.34^{*} \\
8\end{array}$ & $\begin{array}{l}61.67 \pm 2.24^{*} \\
8\end{array}$ & $\begin{array}{l}206.16 \pm 6.29 * \\
*\end{array}$ \\
\hline $\begin{array}{l}\text { Group } \\
\text { IV }\end{array}$ & $\begin{array}{l}300 \mathrm{mg} / \mathrm{k} \\
\mathrm{g}\end{array}$ & $8.48 \pm 0.37 \mathrm{~ns}$ & $\begin{array}{l}5.06 \pm 0.54 n \\
s\end{array}$ & $\begin{array}{l}3.92 \pm 0.12 \mathrm{n} \\
\mathrm{s}\end{array}$ & 1.30:1 & $\begin{array}{l}56.22 \pm 1.29 * \\
\mathrm{a}\end{array}$ & $\begin{array}{l}43.16 \pm 0.88^{*} \\
\text { a }\end{array}$ & $\begin{array}{l}188.2=5.96 \mathrm{~ns} \\
\mathrm{a}\end{array}$ \\
\hline $\begin{array}{l}\text { Group } \\
\text { V }\end{array}$ & $\begin{array}{l}500 \\
\mathrm{mg} / \mathrm{kg}\end{array}$ & $9.12=0.56 \mathrm{aa}$ & $5.16 \pm 0.92 \mathrm{a}$ & $3.96 \pm 0.27 \mathrm{a}$ & 1.31:1 & $\begin{array}{l}31.67 \pm 1.56 \mathrm{n} \\
\mathrm{s} \text { aa }\end{array}$ & $\begin{array}{l}34.65 \pm 0.92 \mathrm{a} \\
\mathrm{a}\end{array}$ & $\begin{array}{l}173.65 \pm 4.18 \mathrm{a} \\
\mathrm{a}\end{array}$ \\
\hline $\begin{array}{l}\text { Groups } \\
\text { VI }\end{array}$ & $\begin{array}{l}100 \\
\mathrm{mg} / \mathrm{kg}\end{array}$ & $8.84 \pm 0.54 a$ & $\begin{array}{l}4.96 \pm 0.55 n \\
s\end{array}$ & $\begin{array}{l}3.88 \pm 0.36 n \\
3\end{array}$ & $1.27: 1$ & $\begin{array}{l}29.66 \pm 1.26 n \\
\text { s aa }\end{array}$ & $\begin{array}{l}31.84 \pm 0.73 a \\
a\end{array}$ & $184.46 \pm 5.18 \mathrm{a}$ \\
\hline
\end{tabular}

Values are mean \pm SD of 5 animals in each group. Statistical analysis ANOVA followed by Dunnett t-test. $* P<0.05$; ** $P$ $<0.01$ as compared with Normal Control to liver damaged control: a $P<0.05$; aa $P<0.01$, aaa $P<0.001$ as compared with liver damaged control to drug treated animal ns: not significant.

Table 3 showed the levels of total bilirubin, conjugated and unconjugated bilirubins and GGTP levels. When compared to normal control rats (Group I), the serum of $\mathrm{CCl}_{4}$ treated rats (Group II) showed a significant elevation in the total bilirubin, conjugated, unconjugated bilirubins and GGTP. In all the other groups treated with the whole plant ethanol extract of C.pusillus (Group III to V), the above said biochemical parameters were found to have decreased when compared to $\mathrm{CCl}_{4}$ treated control rats (Group II). However, the decrease in the concentration of total bilirubin, conjugated, unconjugated bilirubins and GGTP levels were found to be greater in the liver damaged rat group IV, followed by group $\mathrm{V}$, treated with whole plant extracts of C.pusillus respectively.

Table 3: Effect of whole plant ethanol extract of C.pusillus on the serum total, conjugated, unconjugated bilirubin and GGTP levels in the normal control, liver injured and drug treated rats.

\begin{tabular}{|l|l|l|l|l|l|}
\hline \multirow{2}{*}{ Groups } & \multicolumn{5}{|c|}{ Parameters } \\
\cline { 2 - 6 } & Dose & $\begin{array}{l}\text { Total Bilirubin } \\
(\mathrm{Mg} / \mathrm{dl})\end{array}$ & $\begin{array}{l}\text { Conjugated } \\
(\mathrm{Mg} / \mathrm{dl})\end{array}$ & $\begin{array}{l}\text { Unconjugated } \\
(\mathrm{Mg} / \mathrm{dl})\end{array}$ & $\begin{array}{l}\text { GGTP } \\
(\mathrm{U} / \mathrm{L})\end{array}$ \\
\hline Group I & $0.9 \%$ saline & $0.61 \pm 0.011$ & $0.20 \pm 0.031$ & $0.41 \pm 0.31$ & $8.06 \pm 0.36$ \\
\hline Group II & $0.9 \%$ saline & $3.48 \pm 0.72^{* *}$ & $2.31 \pm 0.26^{* *}$ & $1.17 \pm 0.13^{* *}$ & $27.93 \pm 0.27 * *$ \\
\hline Group III & $150 \mathrm{mg} / \mathrm{kg}$ & $3.04 \pm 0.59^{* *}$ & $2.18 \pm 0.13^{* *}$ & $0.86 \pm 0.031^{*}$ & $24.15 \pm 0.92^{* *}$ \\
\hline Group IV & $300 \mathrm{mg} / \mathrm{kg}$ & $2.65 \pm 0.21^{*}$ & $1.36 \pm 0.24^{*} \mathrm{a}$ & $1.29 \pm 0.054 \mathrm{a}$ & $11.36 \pm 0.84 \mathrm{~ns}$ a \\
\hline Group V & $500 \mathrm{mg} / \mathrm{kg}$ & $1.36 \pm 0.63 \mathrm{~ns}$ a & $0.91 \pm 0.054 \mathrm{~ns}$ aa & $0.45 \pm 0.036 \mathrm{aa}$ & $9.15 \pm 0.54 \mathrm{aa}$ \\
\hline Group VI & $100 \mathrm{mg} / \mathrm{kg}$ & $1.06 \pm 0.54 \mathrm{~ns}$ aa & $0.66 \pm 0.018 \mathrm{~ns}$ aa & $0.40 \pm 0.016 \mathrm{aa}$ & $8.36 \pm 0.15 \mathrm{aa}$ \\
\hline
\end{tabular}


Values are mean \pm SD of 5 animals in each group. Statistical $P<0.05$; aa $P<0.01$; aaa $P<0.001$ as compared with liver analysis ANOVA followed by Dunnett t-test. *P $<0.05 ; \quad * *$ Ramaged control to drug treated animal ns: not significant. $<0.01$ as compared with Normal Control to liver damaged control: a $P<0.05$; aa $P<0.01$; aaa $P<0.001$ as compared with liver damaged control to drug treated animal ns: not significant.

The effect of ethanol extract of whole plant of C.pusillus on lipid peroxidation (LPO), glutathione peroxide (GPx), glutathione reductive (GRD), superoxide dismutase (SOD), catalese (CAT) and reduced glutathione (GSH) activities are shown in Table 4. When compared to the normal control rats (Group I), the level of lipid peroxidation increased significantly $(p<0.01)$ and the levels of glutathione peroxidase, superoxide dismutase, catalase and reduced glutathione decreased significantly $(p<0.01)$ in $\mathrm{CCl}_{4}$ intoxicated control rats (Group II). Treatment with the ethanol extract of whole plant of C.pusillus, at the dose of $500 \mathrm{mg} / \mathrm{kg}$ decreased the elevated lipid peroxidation level significantly and restored the altered glutathione peroxidase, glutathione reductase, superoxide dismutase, cutalase and reduced glutathione levels towards normal in a dose dependent manner. The results were well camparable with that of silymarin, the standard drug treated rats.

Table 4: Effect of whole plant ethanol extract of C.pusillus on serum LPO, GPX, GRD, SOD, CAT and GSH activity in the normal control, liver injured and drug treated rats.

\begin{tabular}{|c|c|c|c|c|c|c|c|}
\hline \multirow[b]{2}{*}{ Groups } & \multicolumn{7}{|c|}{ Parameters } \\
\hline & Dose & $\begin{array}{l}\text { LP0 (n mole } \\
\text { of } \mathrm{NDA} / \mathrm{mg} \\
\text { protien) }\end{array}$ & $\begin{array}{l}\text { GPX (umg } \\
\text { Protien) }\end{array}$ & GRD (u'mg & SOD (umg) & CAT (umg) & GSH (umg) \\
\hline Group I & $\begin{array}{l}0.9 \% \\
\text { saline }\end{array}$ & $2.54 \pm 0.073$ & $4.116=0.138$ & $0.421=0.16$ & $0.280=0.039$ & $4.26 \pm 0.31$ & $28.91=0.16$ \\
\hline Group II & $\begin{array}{l}0.9 \% \\
\text { saline }\end{array}$ & $5.98 \pm 0.094 * *$ & $1.841 \pm 0.361^{* 8}$ & $0.265 \pm 0.32 * *$ & $0.136=0.16^{* *}$ & $235 \pm 0.076 * *$ & $16.36=0.27 *$ \\
\hline $\begin{array}{l}\text { Group } \\
\text { III }\end{array}$ & $150 \mathrm{mg} \mathrm{kg}$ & $4.13 \pm 0.054 * *$ & $2.18 \pm 0.549 *$ & $0.306=0.18^{*}$ & $0.196=0.027^{*}$ & $2.92 \pm 0.015 *$ & $21.46 \pm 0.344 \mathrm{~s}$ \\
\hline $\begin{array}{l}\text { Group } \\
\text { IN }\end{array}$ & $300 \mathrm{mg} \mathrm{kg}$ & $3.24 \pm 0.074{ }^{*}$ & $3.8440 .063 \mathrm{a}$ & $0.393=0.11 \mathrm{a}$ & $\begin{array}{l}0.216=0.013 \mathrm{~ms} \\
\mathrm{a}\end{array}$ & 3.8440.077ns a & $26.16 \pm 0.76 \mathrm{a}$ \\
\hline Group V & $50 \mathrm{mg} \mathrm{kg}$ & $3.01 \pm 0.056 \mathrm{aa}$ & $4.36 \pm 0.072 a \mathrm{a}$ & $0.436=0.56 \mathrm{aa}$ & $0.248=0.036 \mathrm{za}$ & $4.66 \pm 0.054 \mathrm{az}$ & $32.16=0.0363 \mathrm{a}$ \\
\hline $\begin{array}{l}\text { Group } \\
\text { VI }\end{array}$ & $100 \mathrm{mg} \mathrm{kg}$ & $2.94=0.086 a \mathrm{a}$ & $3.98 \pm 0.18 \mathrm{aa}$ & $0.441=0.39 \mathrm{az}$ & $0.251=0.035$ aа & $4.13 \pm 0.036 \mathrm{az}$ & $31.84=0.16 \mathrm{aa}$ \\
\hline
\end{tabular}

Values are mean \pm SD of 5 animals in each group. Statistical analysis ANOVA followed by Dunnett t-test. $* P<0.05 ; * * P$ $<0.01$ as compared with Normal Control to liver damaged control: 
as an expression of the functional improvements of hepatocytes.

Alkaline phosphatase concentration is related to the functioning of hepatocytes, high level of alkaline phosphatase in the blood serum is related to the increased synthesis of its by cells lining bile canaliculi usually in response of cholestasis and increased bililary pressure (Graw et al., 1999). Increased level was obtained after $\mathrm{CCl}_{4}$ administration and it was brought to near normal level by C.pusillus whole plant extract treatment.

The liver failure results the drastic come down of total protein and albumin levels of serum because of the hepatotoxicity. The normalized values of total protein and albumin were seen in the group III, IV and V which was because of the rejuvenating or repairing of liver. Ethanol extract of C.pusillus whole plant may have the capability to reform the liver cells by increasing protein values of serum.

The most sensitive tests employed in the diagnosis of hepatic diseases is serum bilirubin. Excessive heme destruction and blockage of bilary tract leads to Hyperbilirubinemia. Due blockage of the bilary tract, there is a mass inhibition of the conjugation reaction and release of unconjugated bilirubin from damaged and dead hepatocytes (Wolf et al., 1997). Ethanol extract of C.pusillus whole plant decreased the level of bilirubin and increased the level of protein suggesting that it offered protection.

The activity of serum $\gamma$-glutamyl transferase is generally increased as a result of liver disease, since $\gamma$-glutamyl transferase is a hepatic microsomal enzyme. Serum $\gamma$-glutamyl transferase is the most useful enzyme in the diagnosis of liver disease. Change in $\gamma$-glutamyl transferase is parallel to those of amino transferase. The critical damage induced by $\mathrm{CCl}_{4}$ elevated the $\gamma$-glutamyl transferase level but, the same attains the normal after treatment with the whole plant of C.pusillus due to its antioxidant potential.

Lipid peroxidation has been identified as the cause for the destructive process of liver injury due to $\mathrm{CCl}_{4}$ administration. In the present study, increased MDA levels in liver indicated increased lipid peroxidation induced by $\mathrm{CCl}_{4}$ (GroupII). This enhanced lipid peroxidation finally triggered hepatic tissue damage and failure of antioxidant defense mechanisms to prevent formation of extravagant free radicals. Treatment with ethanol extract of whole plant of C.pusillus significantly reversed these changes. Hence, it may be possible that the mechanism of hepatoprotection by ethanol extract of whole plant of C.pusillus is due to its antioxidant effect.
Pivotal components of the antioxidant defense system in the body are cellular antioxidant enzymes (SOD and glutathione), which are involved in the reduction of reactive oxygen species (ROS) and peroxides produced in the living organisms as well as in the detoxification of certain compounds of exogenous origin. Thus are cellular antioxidant enzymes playing a primary role in the maintenance of a balanced redox status (Michiels et al., 1994). Hence, they can serve as a potential marker of susceptibility, early and reversible tissue damage, and of decrease in antioxidant defense. (Packer et al., 1994). SOD plays an important role in the elimination of ROS and protects cells against the deleterions effects of super oxide anion derived from the peroxidative process in liver and kidney tissues (Fridovich et al., 1975). In the present study, it was observed that the ethanol extract of C.pusillus whole plant significantly increased the SOD activity in $\mathrm{CCl}_{4}$ intoxicated rats there by diminished $\mathrm{CCl}_{4}$ induced oxidative damage.

CAT is considered as the most important $\mathrm{H}_{2} \mathrm{O}_{2}$ removing enzyme and also a key component of antioxidative defense system. Therefore, the reduction in the activity of catalase may result in a number of deleterious effects due to accumulation of hydrogen peroxide (Chance et al., 1952). In the present study, treatment with ethanol extract of whole plant of C.pusillus, increased the level of catalase significantly in dose dependent manner and protected the liver from $\mathrm{CCl}_{4}$ intoxication.

Glutathione peroxide (GPX) is a selenoenzyme and it protects the cells from damage due to free radicals like hydrogen and liplid peroxides (Zaltzber et al., 1999).It catalyses the reaction of hydroperoxides with reduced glutathione to form glutathione disulphides and reaction product of the hydroperoxides .Glutathione (GSH) extensively found in cells, protects cells from electrophilic attacks provided by xenobiotics such as free radicals and peroxides. GSH deficiency leads to cellular damage in kidney, muscle, lungs, colon, liver, lymphocytes and brain. (Orhan et al., 2007). In the present study, treatment with the whole plant ethanol extract of C.pusillus increased the activities of GPx and $\mathrm{GSH}$ in $\mathrm{CCl}_{4}$ induced liver damaged rats.

\section{CONCLUSION}

This study finally confirms C.pusillus having hepatoprotective effect on hepatic damage induced by $\mathrm{CCl}_{4}$. Thus it can be finalized that mechanism of hepatoprotective activity of C.pusillus whole plant may be due to its free radical scavenging, antioxidant activity and synergistic effect of the phenolics and flavonoids present in the whole plant. The GC-MS analysis of the whole 
plant of C.pusillus, confirmed the presence of 9 , 10-Secocholesta-5,7,10 (19)- triene-3,21,25-triol, $(3 \beta, 5 Z, 7 \mathrm{E})-$,

4-Chloro-17-hydroxy-(17ß) Androst-4-en-3-one, $\alpha$-Tocopherol and Campersterol. The presence of these compounds might be responsible for the hepatoprotective activity.

\section{ACKNOWLEDGEMENT}

The authors are thankful to Dr.R.Sampathraj, Honorary Director, Samsun Clinical Research Laboratory, Thirupur for providing necessary facilities to carry out this work.

\section{REFERENCES}

[1]. Anitha M, Daffodil ED, Muthukumarasamy S and Mohan VR. Hepatoprotective and antioxidant activity of ethanol extract of Cynoglossum zeylanicum (Vahlex Hornem) Thurnb ex Lehm in $\mathrm{CCl} 4$ treated rats. J. Appl. Pharmaceu. Sci. 2012; 2: 099-103.

[2]. Balistrei, W.R. and Shaw, L.M. 1987. Liver function In: Fundamental of Clinical Chemistry, (Ed) Tietz N.W. 3rd edition. W.B. Saunders Company, Philadelphia: 729 - 761 .

[3]. Brinda P, Sasikala P and Purushothaman KK, Pharmacognostic studies on Merugan kizhangu,Bulletin in Med. Ethnobot. Res. 1981; 3:84-96.

[4]. Chance, B., Green Stein, D.S. and Roughton, R.J.W. 1952. The mechanism of catalase action I steady state analysis. Arch Biochem Biophys. 37: 30139

[5]. Clawson, G.A. 1989. Mechanism of carbon tetrachloride hepatotoxicity. Pathol immuunopathol. Res. 8: 104-112.

[6]. Don, G. 1999. Catharanthus Roseus In: Ross I.A (Ed) Medical Plants of The World.Human Press, Totowa, NJ: 109-118.

[7]. Fridovich, I. 1975. Superoxide dismutases. Annu..Rev. Biochem. 44: 147-159.

[8]. Goldberg, D.M. and Spooner, R.J. 1983. Glutothione reductase In: Methods in enzymatic analysis, V.C.H. Weinhem, Germany 258-265

[9]. Graw, A., Cowan, R.A., O'Reilly, D.S.J., Stevant, M.J. and Stephard, J. 1999. Clinical biochemistry-an illustrated color text. Is ted. New York: Churchill Livingstone.

[10]. Lala PK, Lab manuals of Pharmacognosy CSI Publishers and Distributers, Kolkata: 1993.

[11]. Lin, S.C., Lin, C.H., Lin, C.C., Lin, Y.H. and Chen, I.C. 2002. Hepatoprotective effects of Arctium Iappa Linne on liver injuries induced by chronic ethanol consumption and potentiated by carbon tetra chloride J Biomed. Sci. 9: 401-9.

[12]. Lowry OH, Rosenbrough NJ, Farr AL and Randall RJ, Protein measurement with the Folin's phenol reagent, J. Biol. Chem. 1951; 193: 265-275.

[13]. Michiels C, Raes M, Toussaint O, Remacle J. Importance of SE-glutathione peroxidase, catalase, and CU/ZN-SOD for cell survival against oxidative stress. Free Radical Bio Med 1994; 17:235-248.

[14]. Mishra, A., Kumar, P.D., Ranjan, M.M., Arnabaditya, M. and Ashutosh, M. 2009. Analgesic and anti-inflammatory effect Ichnocarpusfrutescensplant parts. Int.J. Ph. Sci. 1: 280 - 283.

[15]. Nkosi, C.Z., Opoku, A.R. and Terblanche, S.E. 2005. Effect of pumpkin (Cucurbitapepo) protein isolate on the activity levels of certain plasma enzymes in CCl4-induced liver injury in lowprotein fed rats. Phy.the.Res. 19: 341-345.

[16]. OECD, (Organization for Economic cooperation and Development). OECD guidelines for the testing of chemicals /Section 4: Health Effects Test No. 423; Acute oral Toxicity - Acute Toxic Class method. OECD. Paris.2002.

[17]. Okhawa, H, Ohishi, N. and Yagi, K. 1979. Assay of lipid peroxidases in animal tissues by thiobarbituric and reaction. Anal. Biochem. 95: 351-358.

[18]. Orhan, D.D., Orhan, N., Ergun, E. and Ergun, F. 2007. Hepatoprotective effect of Vitis vinifera L. leaves on carbontetrachloride- induced acute liver damage in rats. J. Ethnopharmacol 112: 145-151.

[19]. Packer L, Rimbach G, Virgili F (1994) Antioxidant activity and biologic properties of a procyanidin-rich extract from pine (Pinus maritima) bark, pycnogenol. FreeRadic Biol Med 27:704-724.

[20]. Pal A, Banerjee B, Banerjee T, Masih M and Pal K. Hepatoprotective activity of Chenopodium album Linn. plant against Paracetamol induced hepatic injury in rats. Int. J. Pharm. Sci. 2011; 3: 55-57.
[21]. Rajakaruna N, Harris C.S. and Towers G.H.N. Antimicrobial activity of plants collected from serpentine outcrops in Sri Lanka. Pharacological Biology. 2002; 40- 235.

[22]. Shah, M., Jagaer, L., and Grof, P. 2002. Evaluation of the effect of aqueous extract from powders of root, stem, leaves and whole plant of Phyllanthus Debilis against $\mathrm{CCl}_{4}$ induced rat liver dysfunction. Indian Drugs. 39: 333-337.

[23]. Shanmugasundaram R, Kalpanadevi V, Tresina PS, Maruthupandian A and MohanVR,Hepatoprotective activity of ethanol extracts of Clitoria ternatia L. and Cassia angustifolia Vahl. leaf against CCl4 induced liver toxicity in rats. Int Res. J Pharm. 2010; 1: 201205

[24]. Suky TMG, Parthiban B, Kingston C, Tresina soris P and Mohn VR, Hepatoprotective and antioxidant activity effect of Balanites aegyptiaca (L) Del against $\mathrm{CCl} 4$ induce heptotoxicity in rats. Int. J. Pharmaceu. Sci. Res. 2011; 2: 887-892.

[25]. Thangakrishnakumari S, Nishanthini A, Muthukumarasamy S and Mohan VR. Hepatoprotectiveand antioxidant activity of Canscora perfoliata Lam (Gentiaceae) against $\mathrm{CCl} 4$ induced hepatotoxicity I rats. Int. J. Res. Ayur. Pharm. 2012; 3: 822-826.

[26]. Treadway, S., 1998. An ayurvedic approach to a healthy liver. Clinical Nutrition Insights 16, 1-4. Ganga Rao, B., Madukiran, P., and Vijayaraju, A.D. 2012. In vitro evaluation for free radical scavenging activity of methanol leaf extract of Entada pursaetha. Int. J. Pharm.

[27]. Wolf, P.L.1999. Biochemical diagnosis of liver disease. Indian J Clin Biochem. 14: 59-64.

[28]. Zaltzber, H., Kanter, Y., Aviram, M. and Levy, Y. 1999. Increased plasma oxidizability and decreased erythrocyte and plasma antioxidative capacityin patients with NIDDM. Isr. Med. Assoc. J. 1:228-231 